\title{
Pharmacotherapy in pulmonary arterial hypertension: a systematic review and meta-analysis
}

\author{
Christopher J Ryerson", Shalini Nayar, John R Swiston, Don D Sin
}

\begin{abstract}
Background: Previous meta-analyses of treatments for pulmonary arterial hypertension (PAH) have not shown mortality benefit from any individual class of medication.

Methods: MEDLINE, EMBASE, and the Cochrane Central Register of Controlled Trials were searched from inception through November 2009 for randomized trials that evaluated any pharmacotherapy in the treatment of PAH. Reference lists from included articles and recent review articles were also searched. Analysis included randomized placebo controlled trials of at least eight weeks duration and studies comparing intravenous medication to an unblinded control group.
\end{abstract}

Results: 1541 unique studies were identified and twenty-four articles with 3758 patients were included in the meta-analysis. Studies were reviewed and data extracted regarding study characteristics and outcomes. Data was pooled for three classes of medication: prostanoids, endothelin-receptor antagonists (ERAs), and phosphodiesterase type 5 (PDE5) inhibitors. Pooled relative risks (RRs) and 95\% confidence intervals (Cls) were calculated for mortality, 6-minute walk distance, dyspnea scores, hemodynamic parameters, and adverse effects. Mortality in the control arms was a combined $4.2 \%$ over the mean study length of 14.9 weeks. There was significant mortality benefit with prostanoid treatment (RR 0.49, $\mathrm{Cl} 0.29$ to 0.82 ), particularly comparing intravenous agents to control (RR $0.30, \mathrm{Cl}$ 0.14 to 0.63 ). Mortality benefit was not observed for ERAs (RR $0.58, \mathrm{Cl} 0.21$ to 1.60) or PDE5 inhibitors (RR $0.30, \mathrm{Cl}$ 0.08 to 1.08). All three classes of medication improved other clinical and hemodynamic endpoints. Adverse effects that were increased in treatment arms include jaw pain, diarrhea, peripheral edema, headache, and nausea in prostanoids; and visual disturbance, dyspepsia, flushing, headache, and limb pain in PDE5 inhibitors. No adverse events were significantly associated with ERA treatment.

Conclusions: Treatment of PAH with prostanoids reduces mortality and improves multiple other clinical and hemodynamic outcomes. ERAs and PDE5 inhibitors improve clinical and hemodynamic outcomes, but have no proven effect on mortality. The long-term effects of all PAH treatment requires further study.

\section{Background}

Pulmonary arterial hypertension (PAH) is a progressive and debilitating disease characterized by a pathological increase in the resistance of the pulmonary circulation $[1,2]$. The increased pulmonary vascular resistance (PVR) leads to right ventricular dysfunction, exertional impairment, and premature death [3]. The United States national prospective registry for primary pulmonary hypertension reported the median survival for the

\footnotetext{
* Correspondence: cryerson@interchange.ubc.ca

Department of Medicine, University of British Columbia, Vancouver, Canada

idiopathic form of PAH to be only 2.8 years without treatment [3].

There is currently no cure for PAH, however the past two decades have seen significant advances with the development and clinical implementation of a number of medications that specifically target the aberrant regulatory and structural changes in the pulmonary arterial bed $[4,5]$. Three classes of drugs have been developed and approved for the treatment of PAH: prostanoids, endothelin-1 receptor antagonists (ERAs), and phosphodiesterase type 5 (PDE5) inhibitors. All three classes of medication have been shown to favorably affect 
hemodynamic parameters as well as improve functional capacity and exercise tolerance [4]. Although all three classes of drugs have been evaluated in well-designed clinical studies, only one early trial of intravenous epoprostenol was able to detect improvement in mortality in functional class III and IV patients [6]. No other treatment has been demonstrated to have an impact on mortality. Futhermore, adequately powered trials could be considered ethically inappropriate considering the documented symptomatic and functional benefits of many treatments in PAH. This illustrates the role of a meta-analysis in determining the improvement in mortality with these other treatments.

Two meta-analyses have reviewed the treatments of PAH [7,8]. A meta-analysis by Macchia et al in 2007 included some patients with non-PAH pulmonary hypertension and the results of several trials have been reported since this publication [7]. A meta-analysis by Galiè et al published in 2009 concluded that PAH treatment improved mortality, however this conclusion is limited by the pooling of all three classes of PAH treatment and the inclusion of multiple doses of medication, some of which are not approved for clinical use due to either increased adverse effects or lack of efficacy [8]. The failure to include unpublished data in this metaanalysis may have also introduced a publication bias.

We sought to improve upon these previous meta-analyses by addressing these issues. By pooling the available literature, we sought to determine the effect of these classes of medication on total mortality and secondarily to assess their impact on other clinical endpoints, including dyspnea, exercise tolerance, hemodynamics, and adverse effects.

\section{Methods}

\section{Literature search}

We performed a literature search using the MEDLINE and EMBASE databases to identify randomized controlled trials that evaluate the effects of pharmacotherapy on outcomes in PAH. We used the following search terms: pulmonary hypertension, pulmonary arterial hypertension, pulmonary artery hypertension, pulmonary vascular disease, pulmonary heart disease, and pulmonary cardiac disease. The details of the search strategy are summarized in Additional file 1. We also searched the Cochrane Central Register of Controlled Trials and examined bibliographies of retrieved articles and other major review articles. Our search included articles and conference abstracts published from database inception to November 2009 (PUBMED from 1950 to November 2009, EMBASE from 1980 to November 2009). No language restriction was applied. Studies were included if they evaluated adults with PAH and had a follow-up of eight weeks or more. Studies were excluded if they were not double-blind randomized placebo-controlled trials. The only exceptions were studies that evaluated intravenous agents since the use of placebo may be considered unethical in some jurisdictions. We used the Jadad score and the Cochrane Collaboration's tool for assessing methodologic quality and risk of bias, and accepted only those trials with a score of three or greater (two or greater for trials of intravenous agents) using these scales $[9,10]$. We included studies published in abstract form if sufficient information was available to assess methodologic quality. The literature search, data abstraction, and methodologic grading were performed independently by two authors (CJR and SN) using a predefined standardized data abstraction form. All discrepancies were resolved by iteration and consensus.

\section{Endpoints}

The primary end point was total mortality from any cause. Secondary end points included 6 minute walk distance $(6$ MWD), Borg dyspnea scores, functional class (New York Heart Association (NYHA) or World Health Organization (WHO) scores), hemodynamic parameters, and adverse events. Hemodynamic parameters included mean pulmonary artery pressure (mPAP), mean right atrial pressure (mRAP), cardiac index, and pulmonary vascular resistance (PVR) obtained by right heart catheterization. For studies reporting PVR in Woods units, we multiplied this value by 80 to obtain the PVR in dyn-sec/ $\mathrm{cm}^{5}$.

\section{Statistical analysis}

We pooled the data for each end point from individual studies to produce summary effect estimates. Where possible, the endpoints were analyzed based on intention-totreat. We used the $\mathrm{p}$ value or CI when pooling data for studies reporting significance in multiple manners (e.g. $p$ value, CI, standard error, standard deviation). For dichotomous outcomes we calculated a relative risk (RR) and 95\% confidence interval (CI). We calculated weighted mean differences and $95 \%$ CI for continuous variables. In studies reporting only the placebo-corrected mean change, we used this value for the mean change in the intervention group and assigned a value of 0 for the placebo group. Heterogeneity was examined using a $\mathrm{X}^{2}$ test. For outcomes with significant heterogeneity ( $\mathrm{p} \leq 0.10)$ we used a random-effects model to pool the data; otherwise, a fixedeffects model was used. All analyses were conducted using Review Manager statistical software (version 5.0.17 Cochrane Collaboration; Oxford, England). A $p$-value of less than 0.05 was considered significant.

\section{Results}

Twenty-four studies ( $\mathrm{N}=3758$ patients) satisfied the inclusion criteria (Figure 1). The characteristics of these studies are summarized in Additional file 2. 

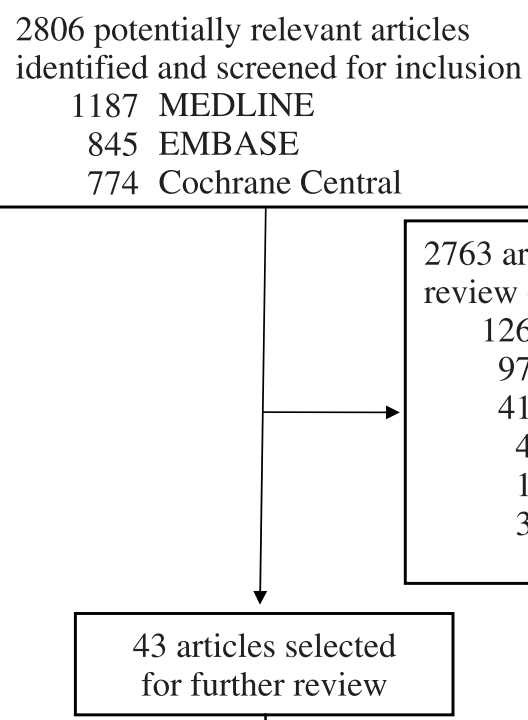

4 articles identified from reference lists

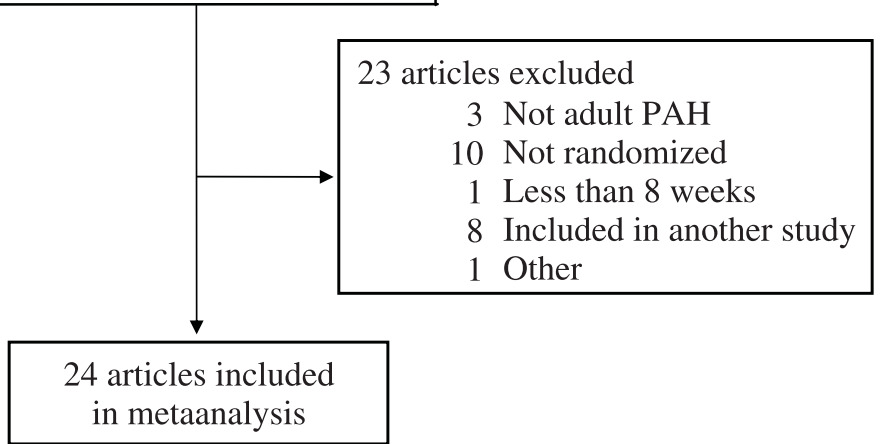

Figure 1 Study selection. PAH, pulmonary arterial hypertension.

\section{Prostanoids}

This analysis was based on 1404 patients from eleven studies that evaluated prostacyclin or prostacyclin analogues, including intravenous epoprostenol and treprostinil, subcutaneous treprostinil, inhaled iloprost and treprostinil, and oral beraprost [6,11-20]. One study included patients with non-PAH forms of pulmonary hypertension [15]. We analyzed data from this study only for the outcomes that described patients with PAH separately. All studies were double-blind randomized controlled trials excluding three studies that compared intravenous epoprostenol to conventional therapy without placebo $[6,13,14]$. One study of intravenous trepostinil compared trepostinil to placebo [18]. The study of intravenous treprostinil and one study of inhaled treprostinil were published in abstract form only, but provided sufficient information for analysis $[17,18]$.

Mortality outcomes were available for ten studies (Figure 2). Overall, compared with conventional therapy or placebo, prostanoids reduced mortality by $51 \%$ (RR 0.49, CI 0.29 to 0.82 ). This benefit was maintained when using a random effects model (RR 0.54, CI 0.32 to 0.94 ). Reduction in mortality was more pronounced when comparing only intravenous agents versus placebo (RR 0.30, CI 0.14 to 0.63), and when correlating risk of mortality to the proportion of patients in the trial with functional class III or IV symptoms (Figure 3).

6 MWD outcome was analyzed in ten of the eleven studies. Borg dyspnea score and NYHA/WHO functional class were analyzed in seven studies, and hemodynamic changes in eight studies. Prostanoids were associated with improvements in the 6 MWD (mean placebo-corrected improvement 29.4 meters, CI 18.1 to 40.7), Borg dyspnea score (improvement -1.10, CI -1.61 to -0.59), WHO and NYHA functional class improvement (RR 3.39, CI 1.56 to 7.36), and hemodynamic parameters (Table 1). Effects were greater for all endpoints when intravenous studies were analyzed separately.

Adverse events were reported in six of the eleven studies $[11,12,14,16,19,20]$. We analyzed events that were reported in three or more individual studies. Adverse events that were significantly increased in the 


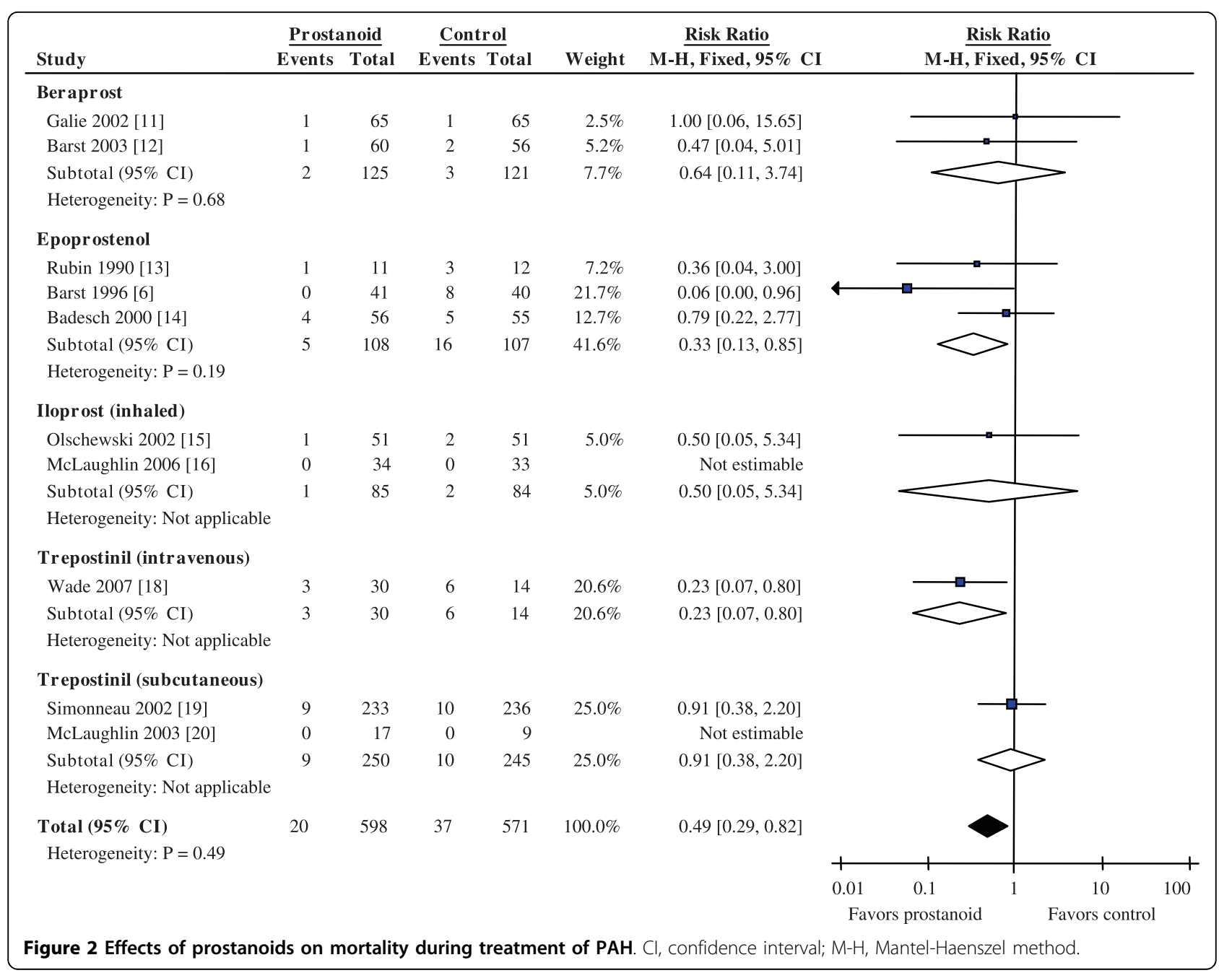

intervention arm are reported in Table 2. These included jaw pain, diarrhea, peripheral edema, headache, and nausea.

\section{Endothelin receptor antagonists}

There were 1273 patients from eight studies that evaluated the use of ERAs, including oral ambrisentan, bosentan, and sitaxsentan [21-28]. Drug dosing varied between and within studies. Summary effect estimates were calculated for some doses including ambrisentan 5 mg daily, bosentan $125 \mathrm{mg}$ twice daily, and sitaxsentan $100 \mathrm{mg}$ daily. These doses were chosen for our metaanalysis because they were 1) the most commonly reported in the retrieved studies, 2) associated with lower incidence of adverse effects; and 3) the standard recommended doses in current practice.

Mortality data were available for all studies (Figure 4). Overall, compared to placebo, ERAs were not associated with a significant change in mortality (RR 0.58 , CI 0.21 to 1.60$)$. Data for $6 \mathrm{MWD}$ was available for seven studies, NYHA/WHO functional class for six, and Borg and hemodynamic changes for five. Benefits were seen in $6 \mathrm{MWD}$ (mean placebo-corrected improvement 38.0 $\mathrm{m}, \mathrm{CI} 27.2$ to 48.7), Borg dyspnea score (improvement -0.57 , CI -0.99 to -0.15 ), functional class improvement (RR 1.67, CI 1.23 to 2.29), and most hemodynamic parameters (Table 1). The two trials of ambrisentan did not report hemodynamic outcomes; however, the effect size for $6 \mathrm{MWD}$ and Borg dyspnea scores was greater in the ambrisentan groups than in either the bosentan or sitaxsentan groups.

Adverse events were reported in all studies, but not all adverse events were reported in each study. We analyzed events that were reported in three or more individual studies. There were no adverse effects that were significantly increased in the intervention arm. Abnormal liver function tests were reported in all studies, however only five studies provided a definition of this adverse effect, with four studies using a transaminitis greater than three times the upper limit of normal, and 


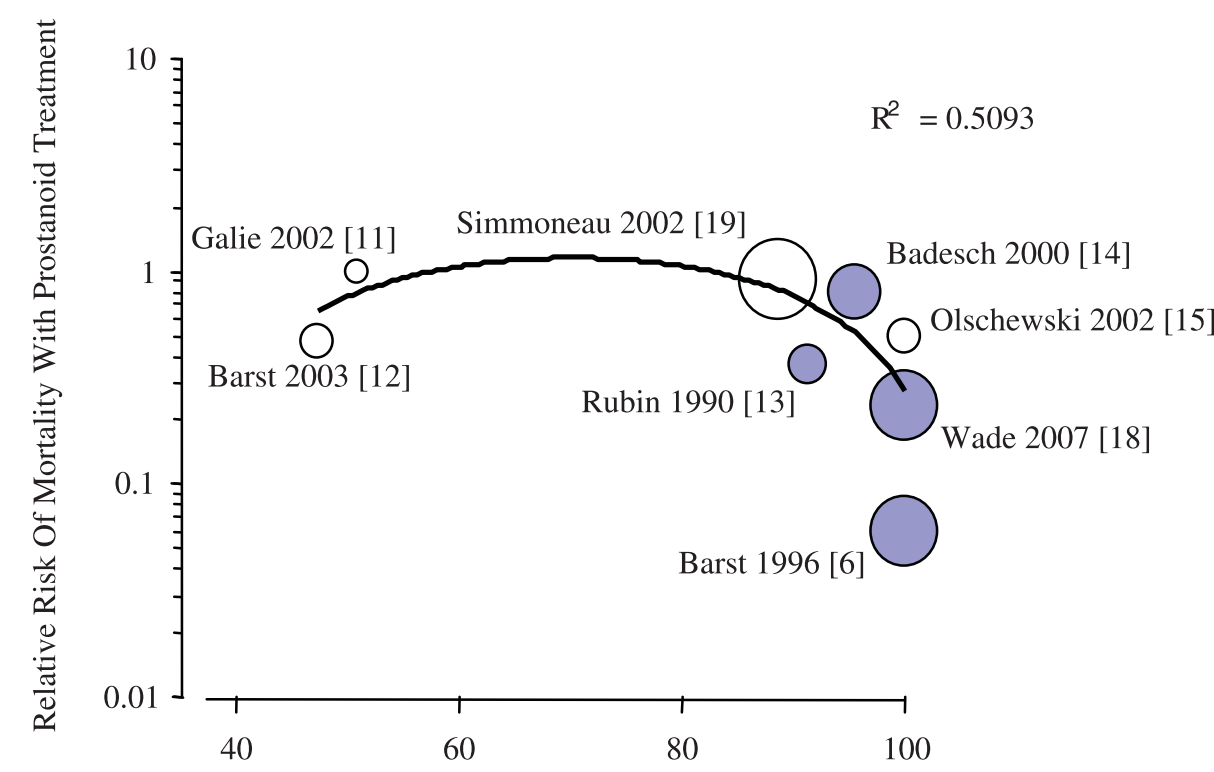

$\%$ Of Patients In Functional Class III or IV For Each Trial

Figure 3 Relationship between mortality rate and functional class severity in individual trials. Relationship between the relative risk of mortality with prostanoid treatment compared to placebo and the proportion of patients in each trial with functional class III or IV symptoms (weighted linear regression). Studies with a greater proportion of functional class III or IV patients showed a greater reduction in mortality $\left(R^{2}=\right.$ 0.5093). Shaded circles represent studies of intravenous prostanoids.

Table 1 Summary of Change in Hemodynamic Outcomes with Intervention Compared to Placebo/Control

\begin{tabular}{lcccc}
\hline Drug Class & mPAP & mRAP & PVR & Cardiac Index \\
\hline Prostanoids & $-4.2(-6.2,-2.1)$ & $-1.6(-2.3,-0.9)$ & $-291(-401,-182)$ & $0.32(0.12,0.52)$ \\
Endothelin receptor antagonists & $-4.9(-6.6,-3.2)$ & $-1.4(-2.9,0.2)$ & $-245(-316,-174)$ & $0.30(0.09,0.51)$ \\
Phosphodiesterase type 5 inhibitors & $-4.2(-5.7,-2.7)$ & $-1.8(-2.8,-0.8)$ & $-192(259,126)$ & $0.39(0.15,0.63)^{*}$ \\
\hline
\end{tabular}

Data are reported as mean placebo/control-corrected change (95\% confidence interval)

mPAP, mean pulmonary artery pressure; mRAP, mean right atrial pressure; PVR, pulmonary vascular resistance

* reported only in Galie et al, 2005 [29]

Table 2 Summary of Significant Adverse Effects with Intervention Compared to Placebo/Control

\begin{tabular}{|c|c|c|c|c|}
\hline Event & Number of studies & Number of participants & $\mathbf{R R}$ & $95 \% \mathrm{Cl}$ \\
\hline \multicolumn{5}{|l|}{ Prostanoids* } \\
\hline Jaw pain & 5 & 893 & 4.87 & 2.01 to 11.76 \\
\hline Diarrhea & 4 & 826 & 2.62 & 1.40 to 4.89 \\
\hline Peripheral edema & 3 & 652 & 2.22 & 1.22 to 4.07 \\
\hline Headache & 4 & 782 & 1.96 & 1.10 to 3.47 \\
\hline Nausea & 5 & 893 & 1.57 & 1.23 to 2.00 \\
\hline \multicolumn{5}{|c|}{ Phosphodiesterase type 5 inhibitors* } \\
\hline Visual disturbance & 3 & 567 & 3.83 & 1.19 to 12.30 \\
\hline Dyspepsia & 3 & 567 & 3.77 & 1.92 to 7.43 \\
\hline Flushing & 3 & 567 & 2.11 & 1.31 to 3.39 \\
\hline Headache & 3 & 567 & 1.73 & 1.19 to 2.51 \\
\hline Limb pain & 3 & 567 & 1.67 & 1.10 to 2.53 \\
\hline
\end{tabular}

$\mathrm{Cl}$, confidence interval; $\mathrm{RR}$, relative risk

* RR \& 95\% Cl calculated for adverse events reported in three or more studies 


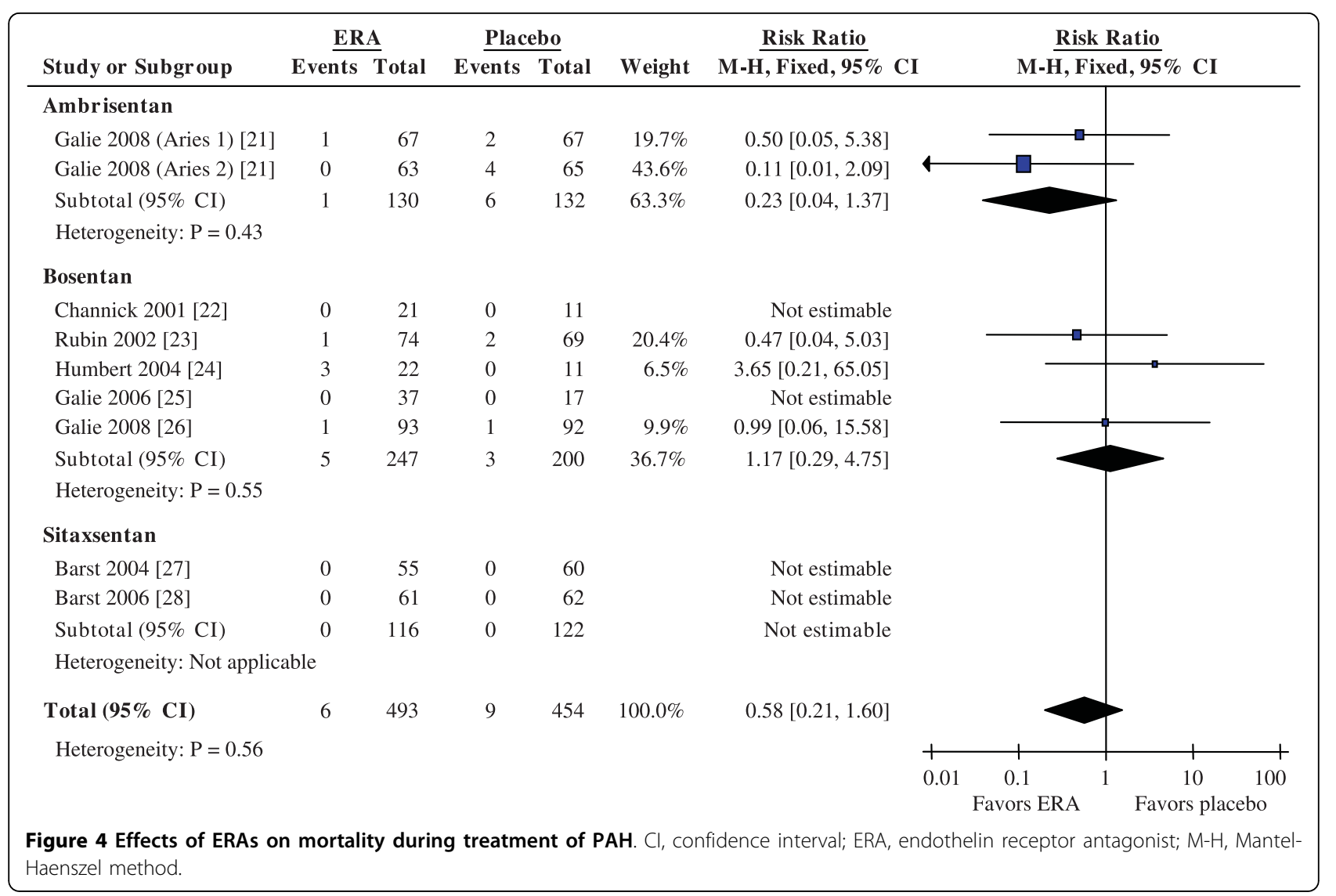

one study using five times the upper limit of normal [21,25-28]. No effect was seen when combining all studies, however a significant increase was found when analyzing data from the studies of bosentan (RR 2.34, CI 1.05 to 5.23$)$.

\section{Phosphodiesterase type $\mathbf{5}$ inhibitors}

Phosphodiesterase inhibitors were assessed in three studies including a total of 950 patients [29-31]. One study included patients randomized to placebo or three doses of sildenafil with results reported for each dose [29]. The second study titrated sildenafil dose to effect with $80 \%$ of patients receiving an $80 \mathrm{mg}$ dose three times daily [30]. The tadalafil study randomized patients to placebo or four doses of tadalafil [31]. Outcome reporting was most complete for the $40 \mathrm{mg}$ group which had the optimal therapeutic effect in this trial. Summary effect estimates were therefore calculated using the 80 $\mathrm{mg}$ groups for sildenafil and $40 \mathrm{mg}$ group for tadalafil.

Mortality data were available for all three studies (Figure 5). Compared to placebo, PDE5 inhibition was not associated with significant change in mortality (RR 0.30, CI 0.08 to 1.08). 6 MWD was reported in three studies and hemodynamic changes in only the two sildenafil sudies. Benefits were seen in 6 MWD (mean placebo-corrected improvement $33.7 \mathrm{~m}$, CI 22.5 to 44.8 ) and all reported hemodynamic parameters (Table 1). Borg dyspnea score and WHO/NYHA FC were reported in only one study and were therefore not analyzed.

We analyzed adverse events that were reported in all three studies. Adverse effects that were significantly increased are reported in Table 2. These included visual disturbance, dyspepsia, flushing, headache, and limb pain.

\section{Other treatments}

Two additional studies satisfied inclusion criteria, but were not analyzed. Terbogrel, a thromboxane receptor antagonist, was evaluated in one trial [32]. This trial was terminated prematurely after the recruitment of seventy-one patients due to excessive leg pain and the subsequent high rate of non-compliance in the intervention group. Based on an intention-to-treat analysis, terbogrel improved pharmacologic endpoints, but had no significant impact on 6 MWD or hemodynamics. Rosuvastatin was assessed for six months in one trial of sixty patients [33]. 6 MWD was a secondary outcome with no change found following rosuvastatin treatment. One German paper examined the effects of molsidomine on gas exchange and hemodynamics in primary pulmonary hypertension, but did not provide enough information for analysis [34]. 


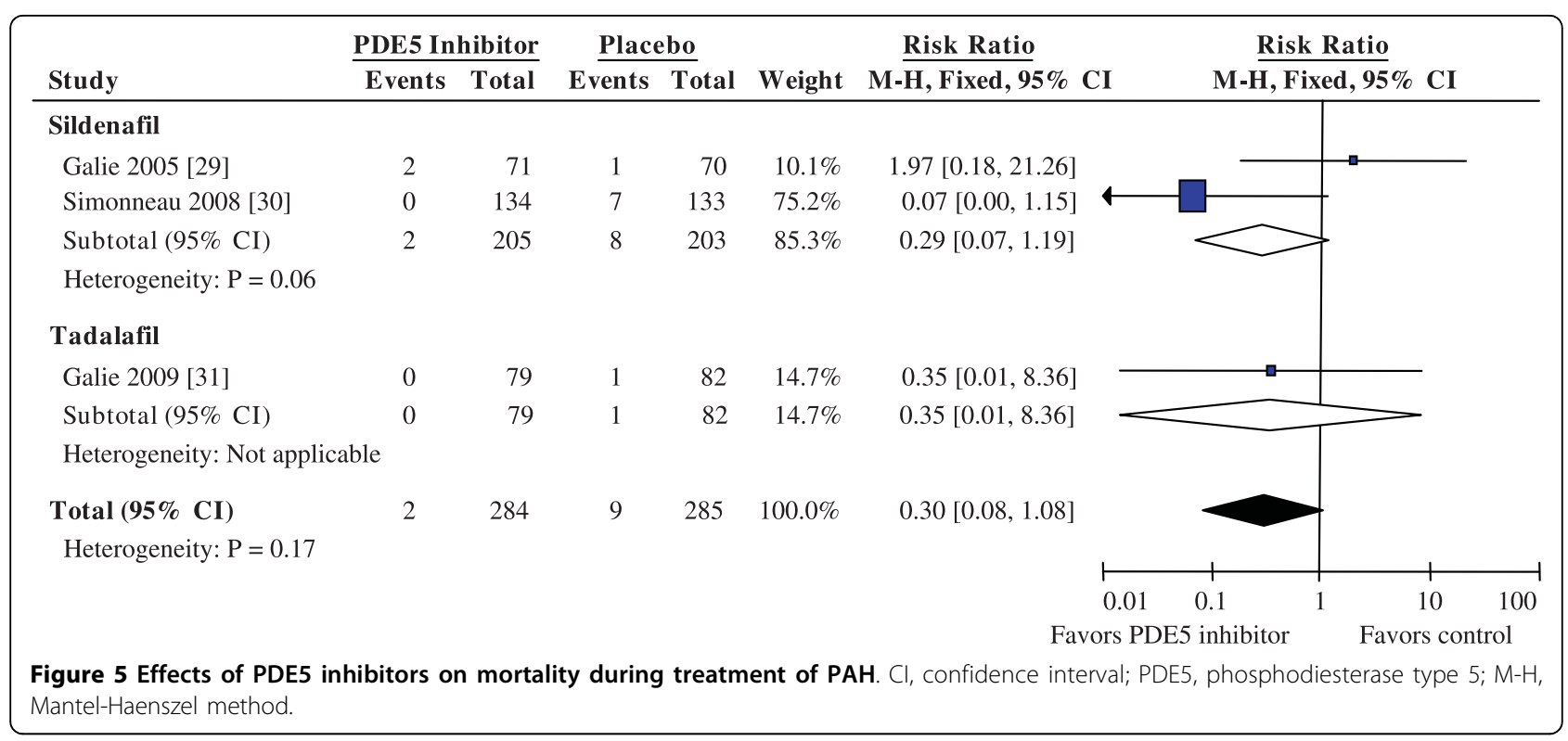

\section{Discussion}

The present study demonstrates that treatment with the prostacyclin and prostacyclin analogue class significantly improves mortality in patients with $\mathrm{PAH}$. Prostanoids, ERAs, and PDE5 inhibitors provide symptomatic relief and improve the functional as well as hemodynamic status of patients with PAH.

The overall prognosis of PAH is very poor with an untreated median survival as short as 3.6 years [3]. In the present study, the overall mortality in the untreated arm was $4.2 \%$ over 14.9 weeks. Thus, mortality reduction is a major goal of pharmacotherapy. However, owing to relatively small sample sizes and short duration of follow-up, the effect of various pharmacotherapies on mortality has been controversial. A recent meta-analysis by Galiè et al concluded that PAH treatment improved mortality, however this conclusion was limited by the combination of all three classes of PAH treatment [8]. Additionally, this meta-analysis included multiple doses of medications, some of which are not approved for clinical use due to lack of efficacy or increased adverse effects. The relatively narrow search strategy used in this prior meta-analysis did not identify three additional studies that were included in the present study, including two abstracts and one full-text publication $[17,18,20]$. We therefore build upon this meta-analysis by separately analyzing individual classes of PAH treatment, by including data only for approved medication doses, and by expanding the search to capture studies published in abstract form. In addition, we include a fourth study that has been recently published [31].

The present study indicates that mortality reduction can be achieved using prostacyclin and prostacyclin analogues. Based on the pooled estimate, the number needed to treat to prevent one death would be thirtytwo patients treated for sixteen weeks. This mortality signal is driven primarily by studies of intravenous prostanoids, particularly those studies that included a greater percentage of patients with functional class III or IV symptoms. With intravenous epoprostenol or treprostinil, only eight patients would require treatment for twelve weeks to prevent one death. The studies of intravenous therapy were among the first trials performed in $\mathrm{PAH}$ and typically included patients with the most severe disease. The placebo arm in these trials had a high mortality rate of $18 \%$, improving the ability to detect mortality benefit from treatment.

Non-intravenous prostanoids, ERAs and PDE5 inhibitors were not associated with a change in mortality. However, these studies often excluded patients with the most severe disease or allowed concurrent therapy with other pulmonary vasodilators. These factors may have lowered the mortality rate in these studies and thus limited the ability to demonstrate improved mortality with these treatments. Treatment with ERAs resulted in a $42 \%$ non-significant improvement in mortality in the 947 subjects included in the pooled analysis. Considering the baseline mortality of only $2 \%$ in the placebo group of these studies, approximately 7,000 subjects would be required to detect this degree of mortality improvement with ERA treatment. This calculation illustrates that such a benefit of ERAs will not be shown with additional studies of similar design. In contrast, based on the relative mortality in the treatment and control groups, the pooled analysis of PDE5 inhibitors is only slightly underpowered to detect a significant difference in mortality. 
The proven mortality benefit of intravenous prostanoids is consistent with the present guidelines, which recommend the use of intravenous epoprostenol as firstline therapy for patients with poor functional class (e.g. NYHA Class IV patients). Despite the lack of proven mortality benefit, non-intravenous prostanoids, ERAs, and PDE5 inhibitors provide improvements in functional class, exercise tolerance, and pulmonary hemodynamics. These drugs may therefore be reasonable therapies for patients with mild to moderate disease with significant functional limitations.

The benefits of these drugs must be carefully balanced against possible toxicities. Bosentan is associated with an increased risk of transaminitis, however our metaanalysis found no evidence of this risk with other ERAs such as sitaxsentan and ambrisentan. These data are consistent with previous studies. Two doses of sitaxsen$\tan$ have been studied as an alternative in patients who failed bosentan therapy due to transaminitis, with only one of twelve patients developing a non-fatal and reversible transaminitis after thirteen weeks of sitaxsentan therapy [35]. This effect appears to be dose-related with the standard dose of $100 \mathrm{mg}$ daily being associated with fewer episodes of liver toxicity [27]. In a second study, only one of thirty-six patients discontinuing bosentan or sitaxsentan developed a transient transaminitis upon starting ambrisentan [36]. The data from the current study, while unable to conclude an absence of liver toxicity with sitaxsentan and ambrisentan, do provide further evidence that these ERAs have less liver toxicity than bosentan.

There are several limitations to this study. First, most of the included trials had a relatively small sample size and short follow-up. Thus, the effect of these drugs on long-term mortality and duration of survival improvement is uncertain, particularly for the ERA and PDE5 inhibitor classes. Second, pooling all trials within each class of medication can be criticized since trials were still heterogeneous, even within a single class. The relatively few trials for any single intervention also limited the ability to perform analyses on individual drugs within each class. Third, while several results of this meta-analysis are positive, it is not entirely clear that outcomes such as a small change in mPAP or small increases in 6 MWD (less than 30 meters) have a strong clinical impact. Fourth, we did not directly evaluate the impact of combined therapies, making it unclear whether an individual agent or the combination itself provides a more beneficial outcome. Only four randomized controlled studies have directly examined the potential benefits of combination versus single agent therapy $[16,24,30,37]$. The primary endpoint was not met in three of these studies [16,24,37]. The single study showing benefit in the primary endpoint reported a small, but statistically significant placebo-corrected improvement of $28.8 \mathrm{~m}$ in $6 \mathrm{MWD}$ [30]. Finally, current guidelines recommend several other treatments for $\mathrm{PAH}$ [4]. Supplemental oxygen and diuretics are recommended for symptomatic control while warfarin and calcium channel blockers are recommended in some forms of PAH. Our search did not identify any randomized placebo-controlled trials that evaluated oxygen, diuretics, warfarin, or calcium channel blockers, though several observational studies suggest their benefit in PAH [38-40].

\section{Conclusions}

The present robust meta-analysis suggests that prostanoids, ERAs, and PDE5 inhibitors all confer a therapeutic benefit. Of these, only intravenous prostacyclins has a proven survival benefit, particularly in patients with severe disease. Non-intravenous prostanoids, ERAs, and PDE5 inhibitors have not been shown to improve mortality, however these agents have not been adequately studied in patients with the most severe disease. Additional studies will be required to determine the optimal dose and duration of these therapies in exacting the best possible outcomes at the lowest cost and risk of adverse events for patients.

\section{List of abbreviations}

6 MWD: 6-minute walk distance; CI: 95\% confidence interval; ERA: endothelin receptor antagonist; mPAP: mean pulmonary artery pressure; mRAP: mean right atrial pressure; NYHA: New York Heart Association; PAH: pulmonary arterial hypertension; PDE5: phosphodiesterase type 5; PVR: pulmonary vascular resistance; RR: relative risk; WHO: World Health Organization.

\footnotetext{
Additional file 1: Search Filters. Search filters used for PUBMED, EMBASE, and the Cochrane Central Register of Controlled Trials. Click here for file

[http://www.biomedcentral.com/content/supplementary/1465-9921-1112-S1.XLS ]

Additional file 2: Characteristics of Included Trials. BID, twice daily; $C H D$, congenital heart disease; CTD, connective tissue disease; IPAH, idiopathic pulmonary arterial hypertension; mPAP, mean pulmonary artery pressure; NR, not reported; QID, four times daily; Scl, Scleroderma; TID, three times daily. ${ }^{*}$ Mean dose. ${ }^{+}$Median dose. ${ }^{*}$ Included some patients with chronic thromboembolic pulmonary hypertension; analyzed patients with pulmonary arterial hypertension that were reported separately. ${ }^{\S}$ Included 61 open-label bosentan patients that were not included in this data.

Click here for file

[http://www.biomedcentral.com/content/supplementary/1465-9921-1112-S2.XLS]
}

\section{Acknowledgements}

The authors would like to thank Kathryn Hornby for her assistance in developing the search strategy. 


\section{Authors' contributions}

CJR and DDS conceived the study design. CJR and SN performed the search and data abstraction. All authors participated in data analysis and interpretation. All authors participated in drafting the manuscript. All authors read and approved the final manuscript.

\section{Competing interests}

The authors CJR, SN, DDS have no competing interests. JRS has received honoraria from Actelion Pharmaceuticals and Pfizer/Encysive for speaking engagements as well as participation in advisory boards for GSK, Pfizer, and Actelion Pharmaceuticals. Assistance for participation in educational activities has also been received from Actelion Pharmaceuticals and Pfizer/Encysive. JRS does not have ongoing contractual or financial relationships with any of these companies. There was no funding provided for this study.

Received: 13 November 2009

Accepted: 29 January 2010 Published: 29 January 2010

\section{References}

1. Voelkel NF, Tuder RM, Weir EK, Rubin L, Rich S: Pathophysiology of primary pulmonary hypertension. Primary Pulmonary Hypertension New York, NY: Marcel Dekker 1997, 83-129.

2. Voelkel NF, Quaife RA, Leinwand LA, Barst RJ, McGoon MD, Meldrum DR, Dupuis J, Long CS, Rubin LJ, Smart FW, Suzuki YJ, Gladwin M, Denholm EM, Gail DB, National Heart, Lung, and Blood Institute Working Group on Cellular and Molecular Mechanisms of Right Heart Failure: Right ventricular function and failure: report of a National Heart, Lung, and Blood Institute working group on cellular and molecular mechanisms of right heart failure. Circulation 2006, 114:1883-1891.

3. D'Alonzo GE, Barst RJ, Ayres SM, Bergofsky EH, Brundage BH, Detre KM, Fishman AP, Goldring RM, Groves BM, Kernis JT, et al: Survival in patients with primary pulmonary hypertension. Results from a national prospective registry. Ann Intern Med 1991, 115:343-349.

4. McLaughlin W, Archer SL, Badesch DB, Barst RJ, Farber HW, Lindner JR, Mathier MA, McGoon MD, Park MH, Rosenson RS, Rubin LJ, Tapson VF, Varga J, Harrington RA, Anderson JL, Bates ER, Bridges CR, Eisenberg MJ, Ferrari VA, Grines CL, Hlatky MA, Jacobs AK, Kaul S, Lichtenberg RC, Lindner JR, Moliterno DJ, Mukherjee D, Pohost GM, Rosenson RS, Schofield RS, Shubrooks SJ, Stein JH, Tracy CM, Weitz HH, Wesley DJ, ACCF/ AHA: ACCF/AHA 2009 expert consensus document on pulmonary hypertension: a report of the American College of Cardiology Foundation Task Force on Expert Consensus Documents and the American Heart Association: developed in collaboration with the American College of Chest Physicians, American Thoracic Society, Inc., and the Pulmonary Hypertension Association. Circulation 2009, 119:2250-2294.

5. Farber HW, Loscalzo J: Pulmonary arterial hypertension. $N$ Engl J Med 2004, 351:1655-1665.

6. Barst RJ, Rubin LJ, Long WA, McGoon MD, Rich S, Badesch DB, Groves BM, Tapson VG, Bourge RC, Brundage BH, Koerner K, Langleben D, Keller CA, Murali S, Uretsky B, Clayton LM, Jobsis MM, Blackburn SD, Shortino D, Crow JW: A comparison of continuous intravenous epoprostenol (prostacyclin) with conventional therapy for primary pulmonary hypertension. The Primary Pulmonary Hypertension Study Group. N Engl J Med 1996, 334:296-302

7. Macchia A, Marchioli R, Marfisi R, Scarano M, Levantesi G, Tavazzi L, Tognoni G: A meta-analysis of trials of pulmonary hypertension: a clinical condition looking for drugs and research methodology. Am Heart J 2007, 153:1037-1047

8. Galiè N, Manes A, Negro L, Palazzini M, Bacchi-Reggiani ML, Branzi A: A meta-analysis of randomized controlled trials in pulmonary arterial hypertension. Eur Heart J 2009, 30:394-403.

9. Higgins JPT, Green S: Cochrane Handbook for Systematic Reviews of Interventions Version 5.0.1 [updated September 2008]. The Cochrane Collaboration 2008http://www.cochrane-handbook.org.

10. Jadad AR, Moore RA, Carroll D, Jenkinson C, Reynolds DJ, Gavaghan DJ, McQuay HJ: Assessing the quality of reports of randomized clinical trials: is blinding necessary?. Control Clin Trials 1996, 17:1-12.

11. Galiè N, Humbert $M$, Vachiéry JL, Vizza $C D$, Kneussl $M$, Manes $A$, Sitbon $O$, Torbicki A, Delcroix M, Naeije R, Hoeper M, Chaouat A, Morand S, Besse B, Simonneau G, Arterial Pulmonary Hypertension and Beraprost European
(ALPHABET) Study Group: Effects of beraprost sodium, an oral prostacyclin analogue, in patients with pulmonary arterial hypertension: a randomized, double-blind, placebo-controlled trial. J Am Coll Cardiol 2002, 39:1496-1502.

12. Barst RJ, McGoon M, McLaughlin V, Tapson V, Rich S, Rubin L, Wasserman K, Oudiz R, Shapiro S, Robbins IM, Channick R, Badesch D, Rayburn BK, Flinchbaugh R, Sigman J, Arneson C, Jeffs R, Beraprost Study Group: Beraprost therapy for pulmonary arterial hypertension. J Am Coll Cardiol 2003, 41:2119-2125.

13. Rubin $L$, Mendoza J, Hood M, McGoon M, Barst R, Williams WB, Diehl JH, Crow J, Long W: Treatment of primary pulmonary hypertension with continuous intravenous prostacyclin (epoprostenol). Results of a randomized trial. Ann Intern Med 1990, 112:485-491.

14. Badesch DB, Tapson VF, McGoon MD, Brundage BH, Rubin LJ, Wigley FM, Rich S, Barst RJ, Barrett PS, Kral KM, Jöbsis MM, Loyd JE, Murali S, Frost A, Girgis R, Bourge RC, Ralph DD, Elliott CG, Hill NS, Langleben D, Schilz RJ, McLaughlin W, Robbins IM, Groves BM, Shapiro S, Medsger TA Jr: Continuous intravenous epoprostenol for pulmonary hypertension due to the scleroderma spectrum of disease. A randomized, controlled trial. Ann Intern Med 2000, 132:425-434.

15. Olschewski $H$, Simonneau $G$, Galiè N, Higenbottam T, Naeije R, Rubin $L$, Nikkho S, Speich R, Hoeper MM, Behr J, Winkler J, Sitbon O, Popov W, Ghofrani HA, Manes A, Kiely DG, Ewert R, Meyer A, Corris PA, Delcroix M, Gomez-Sanchez M, Siedentop H, Seeger W, Aerosolized lloprost Randomized Study Group: Inhaled iloprost for severe pulmonary hypertension. N Engl J Med 2002, 347:322-329

16. McLaughlin W, Oudiz RJ, Frost A, Tapson VF, Murali S, Channick RN, Badesch DB, Barst RJ, Hsu HH, Rubin LJ: Randomized study of adding inhaled iloprost to existing bosentan in pulmonary arterial hypertension. Am J Respir Crit Care Med 2006, 174:1257-126.

17. McLaughlin W, Gaine SP, Barst RJ, Oudiz RJ, Bourge RC, Frost A, Robbins IM, Tapson VF, McGoon MD, Badesch DB, Sigman J, Roscigno R, Blackburn SD, Arneson C, Rubin LJ, Rich S, Treprostinil Study Group: Efficacy and Safety of Inhaled Treprostinil Sodium in Patients with Pulmonary Arterial Hypertension (PAH). Am J Respir Crit Care Med 2008, 177:A965.

18. Wade M: Intravenous treprostinil in pulmonary arterial hypertension: a controlled trial in India. Chest 2007, 132:635b-636.

19. Simonneau G, Barst RJ, Galiè N, Naeije R, Rich S, Bourge RC, Keogh A, Oudiz R, Frost A, Blackburn SD, Crow JW, Rubin LJ, Treprostinil Study Group: Continuous subcutaneous infusion of trepostinil, a prostacyclin analogue, in patients with pulmonary arterial hypertension: a doubleblind, randomized, placebo-controlled trial. Am J Respir Crit Care Med 2002, 165:800-804

20. McLaughlin W, Gaine SP, Barst RJ, Oudiz RJ, Bourge RC, Frost A, Robbins IM, Tapson VG, McGoon MD, Badesch DB, Sigman J, Roscigno R, Blackburn SD, Arneson C, Rubin LJ, Rich S, Trepostinil Sutdy Group: Efficacy and safety of trepostinil: an epoprostenol analog for primary pulmonary hypertension. J Cardiovasc Pharmacol 2003, 41:293-299.

21. Galiè N, Olschewski H, Oudiz RJ, Torres F, Frost A, Ghofrani HA, Badesch DB, McGoon MD, McLaughlin W, Roecker EB, Gerber MJ, Dufton C, Wiens BL, Rubin $\sqcup$, , Ambrisentan in Pulmonary Arterial Hypertension, Randomized, Double-Blind, Placebo-Controlled, Multicenter, Efficacy Studies (ARIES) Group: Ambrisentan for the treatment of pulmonary arterial hypertension: results of the ambrisentan in pulmonary arterial hypertension, randomized, double-blind, placebo-controlled, multicenter, efficacy (ARIES) study 1 and 2. Circulation 2008, 117:3010-3019.

22. Channick RN, Simonneau G, Sitbon O, Robbins IM, Frost A, Tapson VF, Badesch DB, Roux S, Rainisio M, Bodin F, Rubin LJ: Effects of the dual endothelin-receptor antagonist bosentan in patients with pulmonary hypertension: a randomized placebo-controlled study. Lancet 2001, 358:1119-1123.

23. Rubin LJ, Badesch DB, Barst RJ, Galie N, Black CM, Keogh A, Pulido T, Frost A, Roux S, Leconte I, Landzberg M, Simonneau G: Bosentan therapy for pulmonary arterial hypertension. N Engl J Med 2002, 346:896-903.

24. Humbert M, Barst RJ, Robbins IM, Channick RN, Galiè N, Boonstra A, Rubin $L$, Horn EM, Manes A, Simonneau G: Combination of bosentan with epoprostenol in pulmonary arterial hypertension: BREATHE-2. Eur Respir J 2004, 24:353-359.

25. Galiè N, Beghetti M, Gatzoulis MA, Granton J, Berger RM, Lauer A, Chiossi E, Landzberg M, Bosentan Randomized Trial of Endothelin Antagonist Therapy-5 (BREATHE-5) Investigators: Bosentan therapy in patients with 
Eisenmenger syndrome: a multicenter, double-blind, randomized, placebo-controlled study. Circulation 2006, 114:48-54.

26. Galiè N, Rubin Lj, Hoeper M, Jansa P, Al-Hiti H, Meyer G, Chiossi E, KusicPajic A, Simonneau G: Treatment of patients with mildly symptomatic pulmonary arterial hypertension with bosentan (EARLY study): a doubleblind, randomized controlled trial. Lancet 2008, 371:2093-2100.

27. Barst RJ, Langleben D, Frost A, Horn EM, Oudiz R, Shapiro S, McLaughlin V, Hill N, Tapson VF, Robbins IM, Zwicke D, Duncan B, Dixon RA, Frumkin LR, STRIDE-1 Study Group: Sitaxsentan therapy for pulmonary arterial hypertension. Am J Respir Crit Care Med 2004, 169:441-447.

28. Barst RJ, Langleben D, Badesch D, Frost A, Lawrence EC, Shapiro S, Naeije R, Galie N, STRIDE-2 Study Group: Treatment of pulmonary arterial hypertension with the selective endothelin-A receptor antagonist sitaxsentan. J Am Coll Cardiol 2006, 47:2049-2056.

29. Galiè N, Ghofrani HA, Torbicki A, Barst RJ, Rubin LJ, Badesch D, Fleming T, Parpia T, Burgess G, Branzi A, Grimminger F, Kurzyna M, Simonneau G, Sildenafil Use in Pulmonary Arterial Hypertension (SUPER) Study Group: Sildenafil citrate therapy for pulmonary arterial hypertension. N Engl J Med 2005, 353:2148-2157.

30. Simonneau G, Rubin $L J$, Galiè $N$, Barst RJ, Fleming TR, Frost $A E$, Engel PJ, Kramer MR, Burgess G, Collings L, Cossons N, Sitbon O, Badesch DB, PACES Study Group: Addition of sildenafil to long-term intravenous epoprostenol therapy in patients with pulmonary arterial hypertension: a randomized trial. Ann Intern Med 2008, 149:521-530.

31. Galiè N, Brundage BH, Ghofrani HA, Oudiz RJ, Simonneau G, Safdar Z, Shapiro S, White RJ, Chan M, Beardsworth A, Frumkin L, Barst RJ, Pulmonary Arterial Hypertension and Response to Tadalafil (PHIRST) Study Group: Tadalafil therapy for pulmonary arterial hypertension. Circulation 2009, 119:2894-2903.

32. Langleben D, Christman BW, Barst RJ, Dias VC, Galiè N, Higenbottam TW, Kneussl M, Korducki L, Naeije R, Riedel A, Simonneau G, Hirsch AM, Rich S, Robbins IM, Oudiz R, McGoon MD, Badesch DB, Levy RD, Mehta S, Seeger W, Solèr M: Effects of the thromboxane synthetase inhibitor and receptor antagonist terbogrel in patients with primary pulmonary hypertension. Am Heart J 2002, 143:E4.

33. Barreto AC, Maeda NY, Soares RP, Cícero C, Lopes AA: Rosuvastatin and vascular dysfunction markers in pulmonary arterial hypertension: a placebo-controlled study. Braz J Med Biol Res 2008, 41:657-663.

34. Worth H, Siemons H, Rubo J, Goeckenjan G, Loogen F: Acute and chronic effects of molsidomine on gas exchange and hemodynamics in patients with primary vascular pulmonary hypertension. Prax Klin Pneumol 1987, 41:598-599.

35. Benza RL, Mehta S, Keogh A, Lawrence EC, Oudiz RJ, Barst RJ: Sitaxsentan treatment for patients with pulmonary arterial hypertension discontinuing bosentan. J Heart Lung Transplant 2007, 26:63-69.

36. McGoon MD, Frost AE, Oudiz RJ, Badesch DB, Galie N, Olschewski H, McLaughlin W, Gerber MJ, Dufton C, Despain DJ, Rubin LJ: Ambrisentan therapy in patients with pulmonary arterial hypertension who discontinued bosentan or sitaxsentan due to liver function test abnormalities. Chest 2009, 135:122-129.

37. Hoeper MM, Leuchte $H$, Halank M, Wilkens H, Meyer FJ, Seyfarth HJ, Wensel R, Ripken F, Bremer H, Kluge S, Hoeffken G, Behr J: Combining inhaled iloprost with bosentan in patients with idiopathic pulmonary arterial hypertension. Eur Respir J 2006, 28:691-694.

38. Fuster V, Steele PM, Edwards WD, Gersh BJ, McGoon MD, Frye RL: Primary pulmonary hypertension: natural history and the importance of thrombosis. Circulation 1984, 70:580-587.

39. Rich S, Kaufmann E, Levy PS: The effect of high doses of calcium-channel blockers on survival in primary pulmonary hypertension. $N$ Engl I Med 1992, 327:76-81.

40. Frank H, Mlczoch J, Huber K, Schuster E, Gurtner HP, Kneussl M: The effect of anticoagulant therapy in primary and anorectic drug-induced pulmonary hypertension. Chest 1997, 112:714-721.

doi:10.1186/1465-9921-11-12

Cite this article as: Ryerson et al: Pharmacotherapy in pulmonary arterial hypertension: a systematic review and meta-analysis. Respiratory Research 2010 11:12.

\section{Submit your next manuscript to BioMed Central and take full advantage of:}

- Convenient online submission

- Thorough peer review

- No space constraints or color figure charges

- Immediate publication on acceptance

- Inclusion in PubMed, CAS, Scopus and Google Scholar

- Research which is freely available for redistribution

Submit your manuscript at www.biomedcentral.com/submit 